ISSN 2623-6575

GLASILO

UDK $502 / 504$

UDK 58

FUTURE

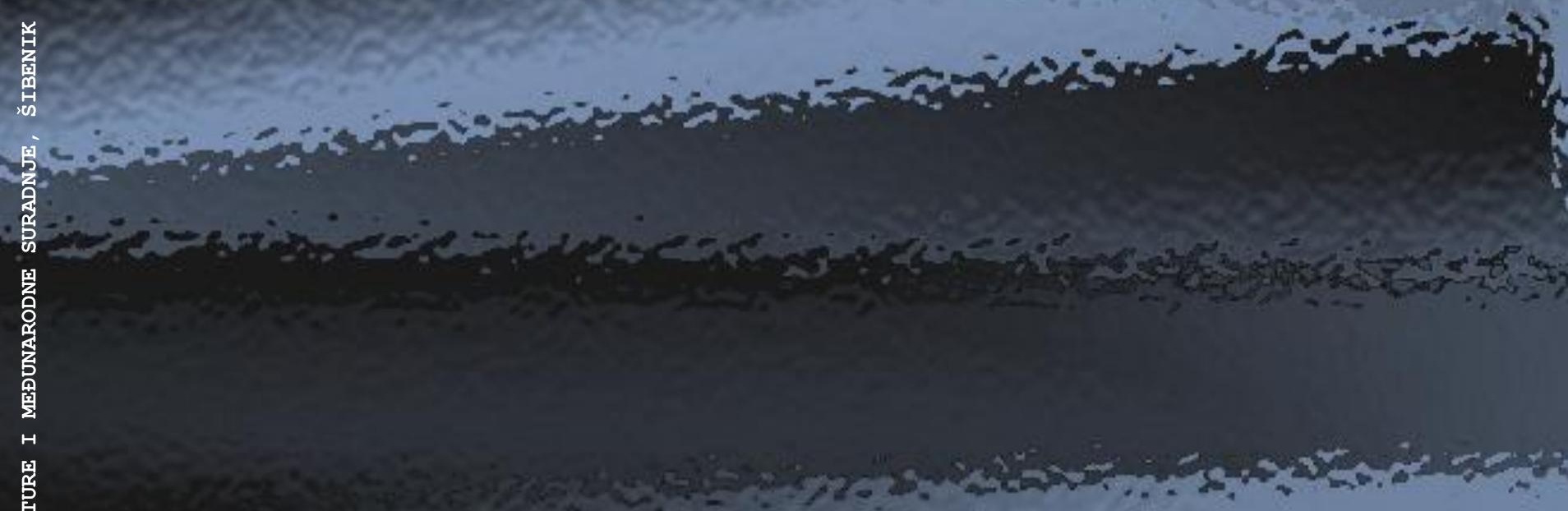

궁

i

$\overbrace{4}^{\circ}$

ठ

㔯

突

递

$\mathbb{4}$

정

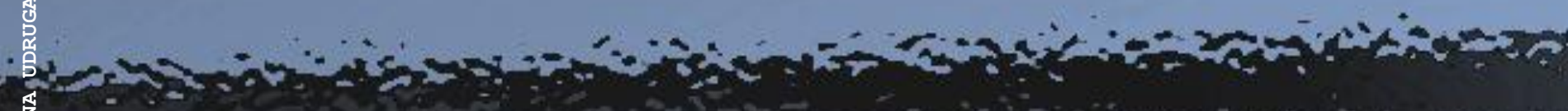

,

焉

钲

否

VOLUMEN 4 BROJ 1

SVIBANJ 2021 . 


\section{Glasilo Future}

\section{Stručno-znanstveni časopis}

\section{Nakladnik: FUTURA \\ F $\mathrm{OT}$ TR $\mathrm{A}$}

Sjedište udruge: Šibenik
Adresa uredništva:

Bana Josipa Jelačića 13 a, 22000 Šibenik, Hrvatska / Croatia

㞗 / 息: +385 (0) 022218133

凹: urednistvo@gazette-future.eu / editors@gazette-future.eu

(3): www.gazette-future.eu

\section{Uređivački odbor / Editorial Board:}

Doc. dr. sc. Boris Dorbić, v. pred. - glavni i odgovorni urednik / Editor-in-Chief

Emilija Friganović, dipl. ing. preh. teh., v. pred. - zamjenica g. i o. urednika / Deputy Editor-in-Chief

Ančica Sečan, mag. act. soc. - tehnička urednica / Technical Editor

Antonia Dorbić, mag. art. - zamjenica tehničke urednice / Deputy Technical Editor

Prof. dr. sc. Željko Španjol

Mr. sc. Milivoj Blažević

Vesna Štibrić, dipl. ing. preh. teh.

Međunarodno uredništvo / International Editorial Board:

Prof. dr. sc. Kiril Bahcevandziev - Portugalska Republika (Instituto Politécnico de Coimbra)

Prof. dr. sc. Martin Bobinac - Republika Srbija (Šumarski fakultet Beograd)

Prof. dr. sc. Zvezda Bogevska - Republika Sjeverna Makedonija (Fakultet za zemjodelski nauki i hrana Skopje)

Dario Bognolo, mag. ing. - Republika Hrvatska (Veleučilište u Rijeci)

Prof. dr. sc. Agata Cieszewska - Republika Poljska (Szkoła Główna Gospodarstwa Wiejskiego w Warszawie)

Dr. sc. Bogdan Cvjetković, prof. emeritus - Republika Hrvatska (Agronomski fakultet Zagreb)

Prof. dr. sc. Duška Ćurić - Republika Hrvatska (Prehrambeno-biotehnološki fakultet Zagreb)

Prof. dr. sc. Margarita Davitkovska - Republika Sjeverna Makedonija (Fakultet za zemjodelski nauki i hrana Skopje)

Prof. dr. sc. Dubravka Dujmović Purgar - Republika Hrvatska (Agronomski fakultet Zagreb)

Prof. dr. sc. Josipa Giljanović - Republika Hrvatska (Kemijsko-tehnološki fakultet u Splitu)

Prof. dr. sc. Semina Hadžiabulić - Bosna i Hercegovina (Agromediteranski fakultet Mostar)

Prof. dr. sc. Péter Honfi - Mađarska (Faculty of Horticultural Science Budapest)

Prof. dr. sc. Mladen Ivić - Bosna i Hercegovina (Univerzitet PIM)

Doc. dr. sc. Anna Jakubczak - Republika Poljska (Uniwersytet Technologiczno-Przyrodniczy w Bydgoszczy)

Doc. dr. sc. Orhan Jašić - Bosna i Hercegovina (Filozofski fakultet Tuzla)

Prof. dr. sc. Tajana Krička - Republika Hrvatska(Agronomski fakultet Zagreb)

Doc. dr. sc. Dejan Kojić - Bosna i Hercegovina (Univerzitet PIM)

Slobodan Kulić, mag. iur. - Republika Srbija (Srpska ornitološka federacija i Confederation ornitologique mondiale)

Prof. dr. sc. Biljana Lazović - Crna Gora (Biotehnički fakultet Podgorica)

Prof. dr. sc. Branka Ljevnaić-Mašić - Republika Srbija (Poljoprivredni fakultet Univerziteta u Novom Sadu)

Doc. dr. sc. Zvonimir Marijanović - Republika Hrvatska (Kemijsko-tehnološki fakultet u Splitu)

Doc. dr. sc. Ana Matin - Republika Hrvatska (Agronomski fakultet Zagreb)

Prof. dr. sc. Bosiljka Mustać - Republika Hrvatska (Sveučilište u Zadru)

Hrv. akademik prof. dr. sc. Stanislav Nakić - Bosna i Hercegovina (Sveučilište Hercegovina Mostar)

Prof. dr. sc. Tatjana Prebeg - Republika Hrvatska (Agronomski fakultet Zagreb)

Prof. dr. sc. Bojan Simovski - Republika Sjeverna Makedonija (Fakultet za šumarski nauki, pejzažna arhitektura i ekoinženering

"Hans Em" Skopje)

Prof. dr. sc. Davor Skejić - Republika Hrvatska (Građevinski fakultet Zagreb)

Prof. dr. sc. Nina Šajna - Republika Slovenija (Fakulteta za naravoslovje in matematiko)

Akademik prof. dr. sc. Refik Šećibović - Bosna i Hercegovina (Visoka škola za turizam i menadžment Konjic)

Prof. dr. sc. Andrej Šušek - Republika Slovenija (Fakulteta za kmetijstvo in biosistemske vede Maribor)

Prof. dr. sc. Elma Temim - Bosna i Hercegovina (Agromediteranski fakultet Mostar)

Mr. sc. Merima Toromanović - Bosna i Hercegovina (Biotehnički fakultet Univerziteta u Bihaću)

Doc. dr. sc. Ivana Vitasović Kosić - Republika Hrvatska (Agronomski fakultet Zagreb) - gostujuća urednica / Guest editor / (2021) 4(1)

Doc. dr. sc. Ana Vujošević - Republika Srbija (Poljoprivredni fakultet Beograd)

Sandra Vuković, mag. ing. - Republika Srbija (Poljoprivredni fakultet Beograd)

Prof. dr. sc. Vesna Židovec - Republika Hrvatska (Agronomski fakultet Zagreb)

Grafička priprema: Ančica Sečan, mag. act. soc.

Objavljeno: 24. svibnja 2021. godine.

Časopis izlazi u elektroničkom izdanju dva puta godišnje, krajem lipnja i svibnja, a predviđena su i dva interdisciplinarna specijalna izdanja tijekom godine iz STEM i ostalih znanstvenih/umjetničkih područja.

Časopis je besplatan. Rukopisi i recenzije se ne vraćaju i ne honoriraju.

Autori/ce su u potpunosti odgovorni/e za sadržaj, kontakt podatke i točnost engleskog jezika.

Umnožavanje (reproduciranje), stavljanje u promet (distribuiranje), priopćavanje javnosti, stavljanje na raspolaganje javnosti odnosno

prerada u bilo kojem obliku nije dopuštena bez pismenog dopuštenja Nakladnika.

Sadržaj objavljen u Glasilu Future može se slobodno koristiti u osobne i obrazovne svrhe uz obvezno navođenje izvora. 


\section{Glasilo Future}

\section{Stručno-znanstveni časopis}

FUTURA - stručno-znanstvena udruga za promicanje održivog razvoja, kulture i međunarodne suradnje, Bana Josipa Jelačića 13 a, 22000 Šibenik, Hrvatska

$$
\text { (2021) } 4 \text { (1) 01-97 }
$$

\section{SADRŽAJ:}

\section{Izvorni znanstveni rad (original scientific paper)}

\section{Ivana Vitasović-Kosić, Lucija Đermek}

Istraživanje korištenja, gospodarenja i zaštite prirodnih dobara u zakonom zaštićenim područjima - stavovi stanovnika rubnih zona PP Medvednica (Zagreb)

Research on the use, management and protection of natural resources in legally protected areas - attitudes of residents of the peripheral zones of the Medvednica

Teja Pintarič, Nina Šajna

Characteristics of heteroblasty in Hladnikia pastinacifolia (Apiaceae), a rare endemic from Slovenia

\section{Pregledni rad (scientific review)}

D. Prlić

Prikaz visinskog gradijenta vegetacije od Malog Platka prema vrhu Snježnika (Hrvatska) A display of the altitudinal vegetation gradient from Mali Platak to the peak of Mt Snježnik (Croatia)

\section{Stručni rad (professional paper)}

\section{J. Juračak, Andreja Martić}

Agroekološke i ekonomske pretpostavke za ekološki uzgoj konoplje za sjeme na području općine Križ

Agro-ecological and economic assumptions for cultivation of organic hemp for seeds in the municipality of Križ

\section{Mara Marić}

Perivoj i vegetacija Vile Čingrija na Boninovu - opservacije terenske nastave treće godine diplomskog studija Povijest Jadrana i Mediterana

The Park and vegetation of Villa Čingrija at Boninovo area - observations from the field teaching of the third year of the graduate study History of the Adriatic and the Mediterranean

\section{Nekategorizirani rad (uncategorised paper)}

V. Šegota, Nina Vuković, A. Alegro

Društvene vijesti i obavijesti

Social news and announcements 


\title{
Prikaz visinskog gradijenta vegetacije od Malog Platka prema vrhu Snježnika (Hrvatska)
}

\section{A display of the altitudinal vegetation gradient from Mali Platak to the peak of Mt Snježnik (Croatia)}

\author{
Dragan Prlić ${ }^{1}$
}

pregledni rad (scientific review)

doi: $10.32779 /$ gf.4.1.3

Citiranje/Citation $^{2}$

\section{Sažetak}

Provođenje studentske terenske nastave podrazumijeva primjenu aktualnih teorijskih spoznaja na praktičan način čime je obuhvaćen obilazak različitih terenskih lokacija, samostalno ispunjavanje terenskih obrazaca te prezentaciju dobivenih rezultata. "Terenska nastava 3 - botanika" naziv je višednevnog terenskog programa koji se izvodi u sklopu preddiplomskog studija biologije na Odjelu za biologiju Sveučilišta Josipa Jurja Strossmayera u Osijeku.

Prolazeći kroz različite vegetacijske zone i pojaseve na području Hrvatske, studenti će ciljano upoznavati karakteristične stanišne tipove i biljne zajednice, pripadajući floristički sastav, zanimljive vegetacijske fenomene poput obrata visinskih pojaseva kao i temeljne ekološke mehanizme koji omogućavaju njihovu pojavnost. Glavnu okosnicu svakog terenskog lokaliteta čini klimazonalna vegetacija čiju izmjenu promatramo kroz visinski gradijent, od nizinskog pojasa Lonjskog polja prema planinskim vrhovima u Gorskom kotaru.

Jedan segment terenske nastave čini upoznavanje vegetacije na potezu od Malog Platka (brdski pojas) prema vrhu Snježnika (planinski pojas). Klimatske prilike područja i dinamika reljefa doprinose izmjeni vegetacije: najniži dio gradi primorska bukova šuma, zatim se redom prolaze gorska šuma bukve i jele, čiste bukove šume pretplaninskog pojasa, klekovina bora krivulja te, konačno, planinski travnjaci na najvišim dijelovima Snježnika. Dodatno, pogledom s vrha Snježnika prema susjednom Risnjaku ili Guslici moguće je upoznati visinski gradijent vegetacije vrlo širokog područja Gorskog kotara.

\footnotetext{
${ }^{1}$ Sveučilište Josipa Jurja Strossmayera u Osijeku, Odjel za biologiju, Ulica cara Hadrijana 8/A, 31000 Osijek, Republika Hrvatska.

*E-mail:dprlic@biologija.unios.hr.

${ }^{2}$ Prlić, D. (2021). Prikaz visinskog gradijenta vegetacije od Malog Platka prema vrhu Snježnika (Hrvatska). Glasilo Future, 4(1), 33-52. / Prlić, D. (2021). A display of the altitudinal vegetation gradient from Mali Platak to the peak of Mt Snježnik (Croatia). Glasilo Future, 4(1), 33-52.
} 
Predviđene terenske aktivnosti prilika su studentima za nadogradnju teorijskih spoznaja te stjecanje praktičnih vještina iz područja botanike i ekologije koja proizlaze iz stvarnih primjera flore i vegetacije na području Hrvatske.

Ključne riječi: studentska terenska nastava, flora, vegetacija, ugrožene svojte, Snježnik.

\begin{abstract}
Conducting a student field course involves the application of actual theoretical knowledge in a practical way that includes visiting various field locations, individually completing the field forms and presenting the obtained results. "Field Course 3 - Botany" is a multi-day field programme conducted as part of the undergraduate study of biology at the Department of Biology, Josip Juraj Strossmayer University in Osijek.

Passing through different vegetation zones and belts in Croatia, students will learn about characteristic habitat types and plant communities, floristic composition, interesting vegetation phenomena such as the inversion of vegetation belts, as well as the basic ecological mechanisms that permit their occurrence. The main element of each field site is the climazonal vegetation and its transitions which can be observed through the altitudinal gradient, from the planar belt of Lonjsko polje to the mountain peaks of Gorski kotar.
\end{abstract}

A part of the fieldwork involves studying the vegetation types on the stretch from Mali Platak (montane belt) to the peak of Mt Snježnik (alpine belt). The climatic conditions of the area and local orography patterns contribute to the change of vegetation: the lowest areas are made of littoral beech forest, followed by the altimontane forest of beech and fir, pure beech forests of the subalpine belt, stands of mountain pine and, finally, alpine grasslands which cover the topmost parts of Mt Snježnik. Moreover, from the peak of the Mt Snježnik towards the neighbouring Mt Risnjak or Guslica, altitudinal vegetation gradient of a very wide area of Gorski kotar can be observed.

The planned field activities present an opportunity for students to upgrade their theoretical reach and to acquire practical skills in the field of botany and ecology based on the actual examples of flora and vegetation in Croatia.

Key words: student field course, flora, vegetation, endangered taxa, Snježnik.

\title{
Uvod
}

Obrazovna djelatnost pokretač je prijenosa znanja i vještina, uključujući aktualne spoznaje proizašle iz najnovijih istraživanja, a raznovrstan $\mathrm{i}$ istovremeno prilagođen sadržaj kojega iskusan nastavnik prenosi studentima postaje nezamjenjivi element kvalitetnog odvijanja nastave. Jedan od oblika nastavnih aktivnosti predstavlja i terenski rad. Uz prikladne smjernice, studenti će imati zadatak 
primijeniti i proširiti dosad stečena znanja iz teorijskog oblika nastave te kroz praktični rad steći dodatne kompetencije. Štoviše, predviđeni terenski lokaliteti studentima su u pravilu nepoznati ili bi im u vlastitom aranžmanu bili teško dostupni, stoga koristi od terenskog oblika nastave na ovaj način postaju višestruke.

Tijekom višednevne terenske nastave koja je dio studijskog programa Odjela za biologiju Sveučilišta Josipa Jurja Strossmayera u Osijeku, studenti 3. godine preddiplomskog studija biologije obilaze niz različitih terenskih lokaliteta raspoređenih kroz tri postojeće biogeografske regije Hrvatske: kontinentalnu, alpinsku i mediteransku. U dobro utvrđenom terenskom itineraru, krajem svibnja i početkom lipnja, planirano je upoznavanje vegetacijskog gradijenta te pripadajuće flore i vegetacijskih fenomena koji su posljedica različitih kombinacija ekoloških čimbenika.

Terenska nastava sličnog karaktera i tematike upoznavanja vegetacije odvija se i na drugim fakultetima primjerice na predmetu Fitocenologija, Agronomskog fakulteta Sveučilišta u Zagrebu (Vitasović-Kosić i sur., 2020).

Slijedom promjene stanišnih uvjeta, prije svega riječ je o promjenama u nadmorskoj visini, početni segment terenske nastave provodi se na prostoru Parka prirode Lonjsko polje. Pod snažnim utjecajem mikroreljefa i hidrografskih obilježja, studenti imaju mogućnost proučiti poplavne sastojine hrasta lužnjaka (Quercus robur L.) i poljskog jasena (Fraxinus angustifolia Vahl), prostrane pašnjačke i livade košanice te mozaik vodene i močvarne vegetacije uz obale vodotoka i u njihovim zaostalim rukavcima.

Podalje od kontinentalnog utjecaja, otoci Krk i Košljun dobri su primjeri prijelaza iz eumediteranskog u submediteranski te mediteransko-montani tip vegetacije. Blaže klimatske amplitude ispoljavaju se u vegetaciji koju grade sastojine hrsta crnike (Quercus ilex L.) i hrasta medunca (Quercus pubescens Willd.), dok na višim dijelovima značajan udio u vegetaciji zauzima crni grab (Ostrya carpinifolia Scop.).

Na području Gorskog kotara smještena je glavnina lokaliteta predviđenih za terensku nastavu, a iznimno značajan segment nastave predstavlja i planinski masiv Snježnika. Očekivano, veliki prostor i izrazito dinamični reljef omogućavaju pojavu različitih tipova vegetacije duž visinskog gradijenta. Od brdskog do pretplaninskog pojasa na cijelom području prevladavaju sastojine bukve (Fagus sylvatica L.), izuzev gorskog pojasa u kojem značajnu ulogu nose i stabla obične jele (Abies alba Mill.). Konačno, na vršnim grebenima naših planina vegetacija se sastoji od klekovine bora krivulja (Pinus mugo Turra) ili od niza travnjačkih zajednica koje naseljavaju najizloženije površine.

Studijski program "Terenska nastava 3 - botanika" ima za cilj kvalitetnu edukaciju studenata u kontekstu klasične floristike, geobotanike, ekologije bilja i fitocenologije. Po završetku terenskog programa studenti će moći objasniti ekološke čimbenike postanka, razvoja i rasprostranjenosti biljnih zajednica, prepoznati međusobne razlike u florističkom sastavu te uspješno primijeniti fitocenološke metode procjene vegetacije. 


\section{Materijali i metode}

Visinski gradijent terenske nastave obuhvaća prostor od brdskog primorskog (paramediteranskog) pojasa Malog Platka prema planinskom (alpinskom) visinskom pojasu oko vrha Snježnika. Za vrijeme nastave studenti koriste terenske obrasce, prilagođene nastavnim ciljevima, u koje unose niz relevantnih ekoloških parametara (npr. nadmorska visina, nagib i ekspozicija terena) za svaku od terenskih postaja.

Uz klimatske i reljefne elemente, sastavni dio staništa predstavlja i floristička raznolikost. Postojeće biljne vrste potrebno je pravilno determinirati, izvršiti procjenu njihove pokrovnosti te ih priključiti u odgovarajući ekološki sloj (etažu). Sve navedeno vrši se kroz izradu fitocenoloških snimaka kao tipične metode terenskog prikupljanja podataka o vegetaciji (usp. Topić i sur., 2006). Prepoznavanje biljnih vrsta, nakon toga i biljnih zajednica, studenti provode pomoću dostupne literature (Jávorka i Csapody, 1991; Kovačić et al., 2008; Vukelić et al., 2008; Vukelić, 2012; Griebl, 2018; Nikolić, 2019), a najvažnije vegetacijske pojave na terenu potrebno je i fotodokumentirati.

Svi prikupljeni podaci zajednički se analiziraju nakon povratka s terena s konačnim ciljem kako bismo definirali florističke i vegetacijske značajke predmetnog područja. U ovom koraku tumačimo ekološke pojave koje smo opazili na zabilježenim staništima, biljne zajednice i dijagnostičke biljne vrste po kojima ih prepoznajemo, značajke klimazonalne vegetacije, karakteristične procese degradacije i sukcesije te oblike antropogenog utjecaja. Zaključke o dinamici ekoloških čimbenika i posljedičnim razlikama u vegetaciji studenti izvode kroz samostalne prezentacije ili terenska izvješća koja sadrže sve potrebne tekstualne i grafičke elemente proizašle iz nastavnih aktivnosti.

\section{Geografski položaj i osnovne ekološke značajke Snježnika}

Atraktivan i lako pristupačan planinski masiv Snježnika smješten je na području Gorskog kotara, oko $2 \mathrm{~km}$ sjeverozapadno od vrha Risnjaka te zajedno s njime predstavlja dio Nacionalnog parka Risnjak. Nacionalnim parkom Risnjak je proglašen 1953. godine, nakon čega su 1997. godine granice revidirane i proširene na susjedni Snježnik i izvor rijeke Kupe. Ukupna površina područja sada iznosi 6350 ha (Anonymous, 2007). Za ovaj konzervacijski status zaslužan je glasoviti botaničar dr. Ivo Horvat koji je značajni dio života uložio u istraživanje vegetacije Risnjaka (Poljak, 2008). Štoviše, sprječavanje eksploatacije te očuvanje raznolikosti i ekološki povoljnog stanja šuma potpomognuto je dodjeljivanjem statusa nacionalnog parka.

Klimatske prilike, koje generalno vežemo za visoke vegetacijske pojaseve, ističu se osjetno niskim temperaturama, hladnim vjetrovima te prolongiranim zadržavanjem snježnog pokrivača, stoga vegetacijska sezona svoj vrhunac doseže kasnije nego u nižim predjelima. Sve navedeno ostavlja trag na biljni pokrov, posebice na drvenaste vrste koje s porastom nadmorske visine postaju sve jače 
deformirane. Tako u zoni klekovine bora krivulja na Snježniku prosječna godišnja temperatura iznosi svega $1,4^{\circ} \mathrm{C}$, a snježni pokrivač može se na tlu zadržati i 175 dana (Horvat, 1962). Godišnja količina oborina u vršnim dijelovima očekivano je obilna, iznosi $3648 \mathrm{~mm}$. Međutim, silaskom u niže vegetacijske pojaseve klimatski uvjeti postaju sve blaži, a to se ispoljava u vitalnosti drveća. Primjerice, u pretplaninskoj sastojini bukve srednja godišnja temperatura porast ce na oko $4^{\circ} \mathrm{C}$ (Bertović, 1975a).

Uz visinski gradijent vegetacijskih pojaseva kao jedne od glavnih vrijednosti Gorskog kotara, valja istaknuti i njegov orografski karakter koji djeluje kao klimatska barijera između područja hrasta kitnjaka kontinentalnog dijela Hrvatske te bijeloga i crnoga graba Hrvatskog primorja (Horvat, 1952/53). Za fizionomiju krajolika i vegetacijski pokrov Horvat (1962) naglašava važnost geomorfologije, odnosno ukupne raznolikosti reljefnih parametara. Biljne zajednice i floristički sastav tako će se razlikovati na sjeveroistočnoj kopnenoj strani prema obroncima Snježnika, od one na jugozapadnoj primorskoj koja je od Jadranskog mora udaljena svega $12 \mathrm{~km}$.

S najvišim vrhom od 1505 m, masiv Snježnika nešto je niži od Risnjaka (1528 m) i Bjelolasice (1534 m). Naime, ovisno o dogovoru sa studentima ili potencijalnim logističkim okolnostima koji bi otežale pristup do Snježnika, gradijent vegetacije prema planinskom pojasu može se obraditi kroz potonja dva lokaliteta. Ukoliko usporedimo dinamiku reljefa ovih područja, moguće je primijetiti kako su vršni dijelovi Snježnika razvedeniji od Bjelolasice, prožeti brojnim vrletima, no ipak ne izbijaju tako izraženo i strmo poput kamenih gromada oko vrha Risnjaka (usp. Božičević, 1993; Anonymous, 2001). Svi relevantni elementi planinskog terena, poput izloženih vapnenačkih grebena, zaštićenih padina različitog nagiba te dolina i ponikava s pripadajućom vegetacijom, zastupljeni su na svim navedenim lokalitetima iako u različitim omjerima. Povezani su mrežom šumskih cesta i planinarskih staza što olakšava njihovo upoznavanje te kretanje kroz različite visinske pojaseve.

\section{Dosadašnje botaničke spoznaje na širem području Snježnika}

Inicijalna istraživanja flore i vegetacije na području Risnjaka i Snježnika potječu još s kraja 19. stoljeća, a doprinos su domaćih i stranih istraživača s obzirom da su ove planine lako pristupačne te ujedno dobro očuvane od nepovoljnih gospodarskih utjecaja (Horvat, 1950). Najranijim botaničkim spoznajama područja osobito su doprinijeli Dragutin Hirc, Ljudevit Rossi i Stjepan Gjurašin. Glasoviti botaničar Ivo Horvat vlastita istraživanja započinje 1927. godine, a vrlo brzo nakon toga publicira rezultate prikupljene istraživanjem planinskih travnjaka i vegetacije stijena (Horvat, 1930, 1931). Terenski rad intenzivira između 1947. i 1954. godine u nastojanju da se istraživanja vegetacije Gorskog kotara i Hrvatskog primorja povežu s pedološkim i klimatološkim spoznajama. Naročito vrijedni spomena su njegovi detaljni opisi visinske razdiobe klimazonalne vegetacije na primjerima Risnjaka i Snježnika. 
Horvat (1955) komentira sekcije tadašnje vegetacijske karte pri čemu posebno ističe sekciju 1b, koja obuhvaća periferiju Snježnika te dio sjevernog Primorja, kao "najljepši primjer mnogolikosti vegetacije hrvatskog krša". U njoj je prikazan cjelovit visinski gradijent od pojasa bijeloga graba (Carpinus orientalis Mill.) pa sve do planinskih travnjaka. Karta biljnih zajednica jugozapadne Hrvatske (Horvat, 1962) izrađena u četiri sekcije daje izvrstan prikaz raznolikosti i prostornog rasporeda biljnih zajednica toga područja.

Šegulja et al. (1994) predstavljaju rezultate florističkih istraživanja Nacionalnog parka Risnjak. Ukupno su zabilježili 876 svojti vaskularne flore, od toga 18 endemskih vrsta, klasificiranih unutar 92 porodice i 376 rodova. S obzirom na prostranstvo i heterogenost planinskih masiva, vrlo je izgledno kako će buduća istraživanja ovoga tipa proširiti trenutno poznati inventar biljnih vrsta.

\section{Gradijent biljnih zajednica od brdskog prema pretplaninskom pojasu}

Pristupnom cestom prema planinarskom domu Platak, na području oko Malog Platka, nalazi se prva terenska postaja gdje će studenti opažati utjecaj nadmorske visine na ekološke i vegetacijske značajke brdskog primorskog pojasa. Izloženi i jugozapadu okrenuti termofilni obronci Malog Platka stjenovite su fizionomije i plitkog skeletnog tla što stvara pogodno stanište za primorsku bukovu šumu s jesenskom šašikom (Seslerio autumnalis-Fagetum sylvaticae /Horvat/ M. Wraber ex Borhidi 1963). Ona pokriva velike prostore na primorskim padinama Dinarida, pri čemu se u Hrvatskoj nalazi središte njezina areala (Vukelić et al., 2008), a riječ je o našoj najnižoj i najtoplijoj klimazonalnoj fitocenozi kontinentalnog područja iznad Mediterana (Slika 1). U sloju drveća glavnu ulogu nosi bukva (Fagus sylvatica). Velika pokrovnost jesenske šašike (Sesleria autumnalis (Scop.) F. W. Schultz) ističe se u prizemnom sloju, a sastav floru dopunjuju još: medenika (Melittis melissophyllum L.), velecvjetna gorska metvica (Calamintha grandiflora (L.) Moench), šumska ciklama (Cyclamen purpurascens Mill.), gronjasti vratić (Tanacetum corymbosum (L.) Sch. Bip.) i šumski pavlovac (Aremonia agrimonoides (L.) DC.).

Površine koje se ne nalaze pod šumom ili nisu zahvaćene sukcesijom, pripadaju kamenjarskom pašnjaku šaša crljenike i žute kraške zečine (Carici-Centaureetum rupestris Horvat 1931) vrlo šarolikog i bogatog sastava biljnih vrsta. Početkom lipnja cvatu biljke uglavnom niskog rasta i široke palete boja među kojima prevladavaju žuti cvjetovi roda Genista (žutilovka). Kasnije u vegetacijskoj sezoni mijenja se vizura u nešto jednostavniji aspekt s manjim brojem vrsta. Posebno se tada ističu rodovi Seseli (devesilje) i Pseudolysimachion (čestoslavica). Padine Malog Platka povoljnih su uvjeta za nesmetan razvoj mnogih termofilnih vrsta: klasoliki vrisak (Satureja subspicata Bartl. ex Vis.), kamenjarska ili kraška zečina (Centaurea rupestris L.), šaš crljenika (Carex humilis Leyss.), gorski zdravinjak (Seseli libanotis (L.) W. D. J. Koch), Barrelierova čestoslavica (Pseudolysimachion barrelieri (Schott ex Roem. et Schult.) Holub), bojadisarska žutilovka (Genista tinctoria L.) i uskolisna žutilovka (Genista sylvestris Scop.). Od grmolikih biljaka zabilježene su obična dunjarica 
(Cotoneaster integerrimus Medik.), planinska borovica (Juniperus communis L. ssp. nana Syme) i planinski likovac (Daphne alpina L.). S proplanaka Malog Platka pogled se otvara na prostrano Grobničko polje.

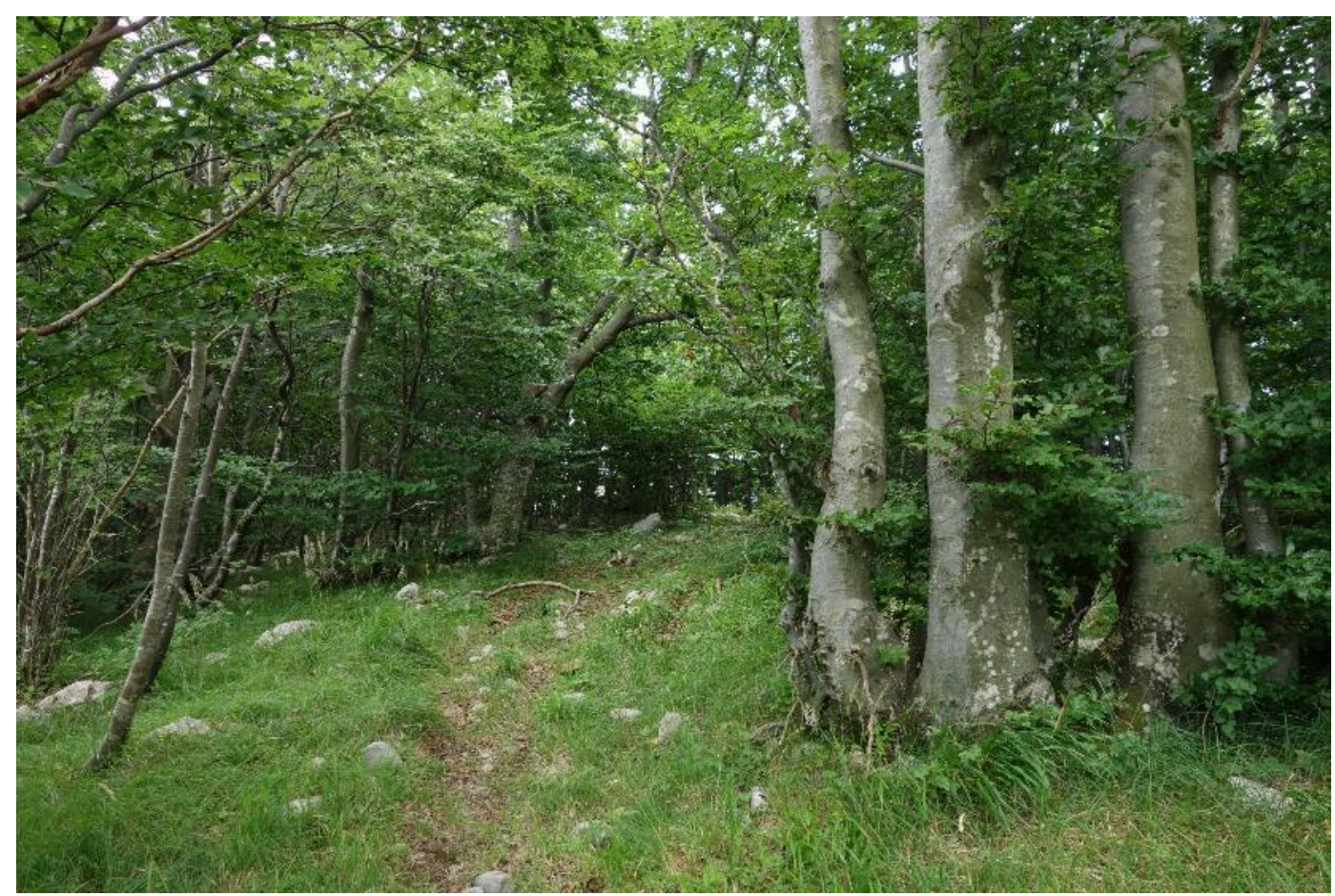

Slika 1. Termofilne padine oko Malog Platka obrasla je primorska bukova šuma s jesenskom šašikom (Seslerio autumnalis-Fagetum sylvaticae). (foto: D. Prlić)

Figure 1. Termophilous slopes around Mali Platak are covered by littoral beech forest with autumn moor grass (Seslerio autumnalis-Fagetum sylvaticae). (photo: D. Prlić)

Padine zapadne ekspozicije iznad Malog Platka prekrivene su bukovo-jelovom šumom s mišjim uhom zapadnih Dinarida (Omphalodo-Fagetum /Tregubov 1957 corr. Puncer 1980/ Martinček et al. 1993). Ova klimazonalna vegetacija zaprema velika prostranstva u gorskom pojasu, a dijelom seže i iznad planinarskog doma Platak. Ekološki je smještena između dva pojasa čistih bukovih šuma (brdskih i pretplaninskih), a uspijeva na gotovo svim tipovima terena (Vukelić i Rauš 1998).

Stabla bukve (Fagus sylvatica) široko su prisutna, dok daljnjim usponom iznad planinarskog doma obična jela (Abies alba Mill.) postaje sve slabije konkurentna pa se ponajprije javlja u donjoj etaži sloja drveća ili pak u sloju grmlja (Slika 2). Od zeljastih biljaka značajne su: proljetno mišje uho (Omphalodes verna Moench), velecvjetna gorska metvica (Calamintha grandiflora (L.) Moench), trolisna režuha (Cardamine trifolia L.), višelisnata režuha (Cardamine kitaibelii Bech.), crvena gorčika (Prenanthes purpurea L.), velika mrtva kopriva (Lamium orvala L.) i dr. Bukvi se u sloju drveća pridružuje gorski javor (Acer pseudoplatanus L.) čija stabla ovdje još nisu deformirana pod teretom snijega. 
U zasjenjenim pukotinama stijena gorskog pojasa nalazimo zajednicu mahovinaste merinke i bijele padimovice (Moehringio-Pseudofumarietum albae Horvat 1962 corr. Trinajstić). U njoj su obilno zastupljene mahovinasta merinka (Moehringia muscosa L.) te paprati smeđa (Asplenium trichomanes L.) i zidna slezenica (Asplenium ruta-muraria L.). Drugdje uz makadam mjestimično se otvaraju mali proplanci koji pripadaju travnjacima uspravnog ovsika i srednjeg trpuca (Bromo-Plantaginetum mediae Horvat 1931). Osobito su živopisni za ljetnog perioda kada populacija žutog volujca (Buphthalmum salicifolium L.) doseže najveću brojnost.

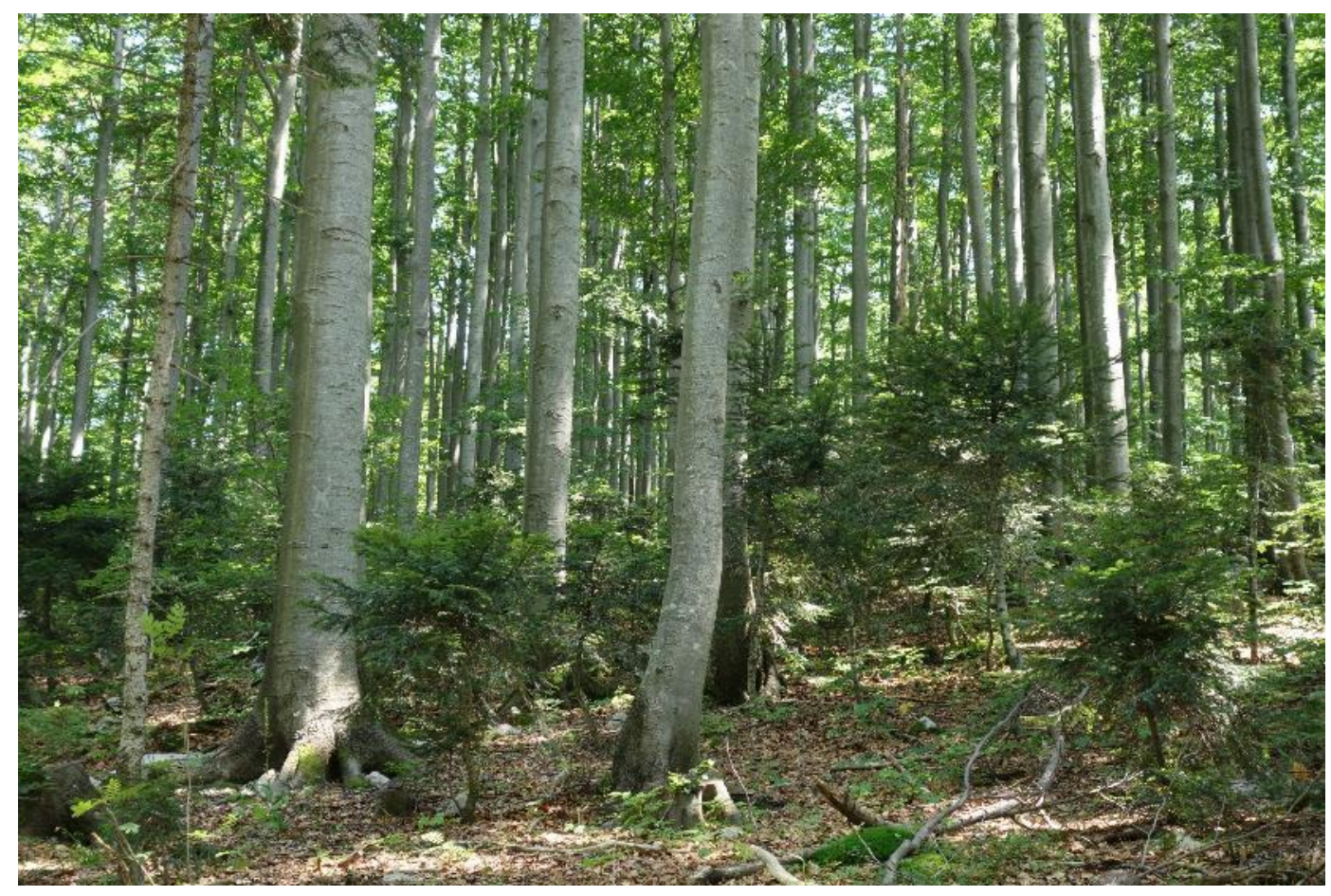

Slika 2. Primjer bukove-jelove šume s mišjim uhom zapadnih Dinarida (Omphalodo-Fagetum). Iznad planinarskog doma Platak prevladava bukva, a jela zaostaje tek u sloju grmlja. (foto: D. Prlić)

Figure 2. An example of the dinaric silver fir-beech forest (Omphalodo-Fagetum). Beech is dominant above the mountan lodge Platak, while silver fir remains in the shrub layer. (photo: D. Prlić)

Široko zavojitu šumsku cestu na području "Veliko Radeševo", koja tijesno prati morfologiju planinskog reljefa, siječe uska planinarska staza sa svih strana okružena tankim stablima bukve, vjerojatno kao posljedica nekadašnje sječe. Njome je jednim dijelom moguće skratiti uspon prema vrhu. Na ovom području obična jela i mnogi gorski elementi polagano izostaju, a bukva gubi na dimenzijama te sve češće poprima tipičnu sabljastu formu karakterističnu za pojas pretplaninske bukove šume s planinskim žabnjakom (Ranunculo platanifolii-Fagetum /Horvat 1938/ Marinček et al. 1993). Deformirane krošnje bukve posljedica su dugog zadržavanja snijega zbog čega ova zajednica dobiva jedinstvenu fizionomsku prepoznatljivost (Slika 3). Pored bukve (Fagus sylvatica) prisutna su, doduše rijetko i pojedinačno, stabla gorskog javora (Acer pseudoplatanus), mukinje (Sorbus aria (L.) Crantz), a vrlo rijetko i smreke (Picea abies (L.) H. Karst.). 
Dijagnostička vrsta zajednice je platanastolisni žabnjak (Ranunculus platanifolius L.), neobični pripadnik roda Ranunculus (žabnjak) bijele boje cvjetova. Prostranstva s medvjeđim lukom (Allium ursinum L.) učestala su pojava prizemnog sloja šume, a floristički sastav još dopunjuju: bijela čemerika (Veratrum album L.), klasasta zečica (Phyteuma spicatum L.), praseće zelje (Aposeris foetida (L.) Less, siva ljepika (Adenostyles alliariae (Gouan) A. Kern.) i širokolisna čestoslavica (Veronica urticifolia Jacq.) kao obilno zastupljena vrsta. Sastojine imaju primarno zaštitni karakter u smislu sprječavanja erozije, ublažavanja klimatskih uvjeta te služe kao stanište za divlje životinje poput velikog tetrijeba (Vukelić et al., 2008).

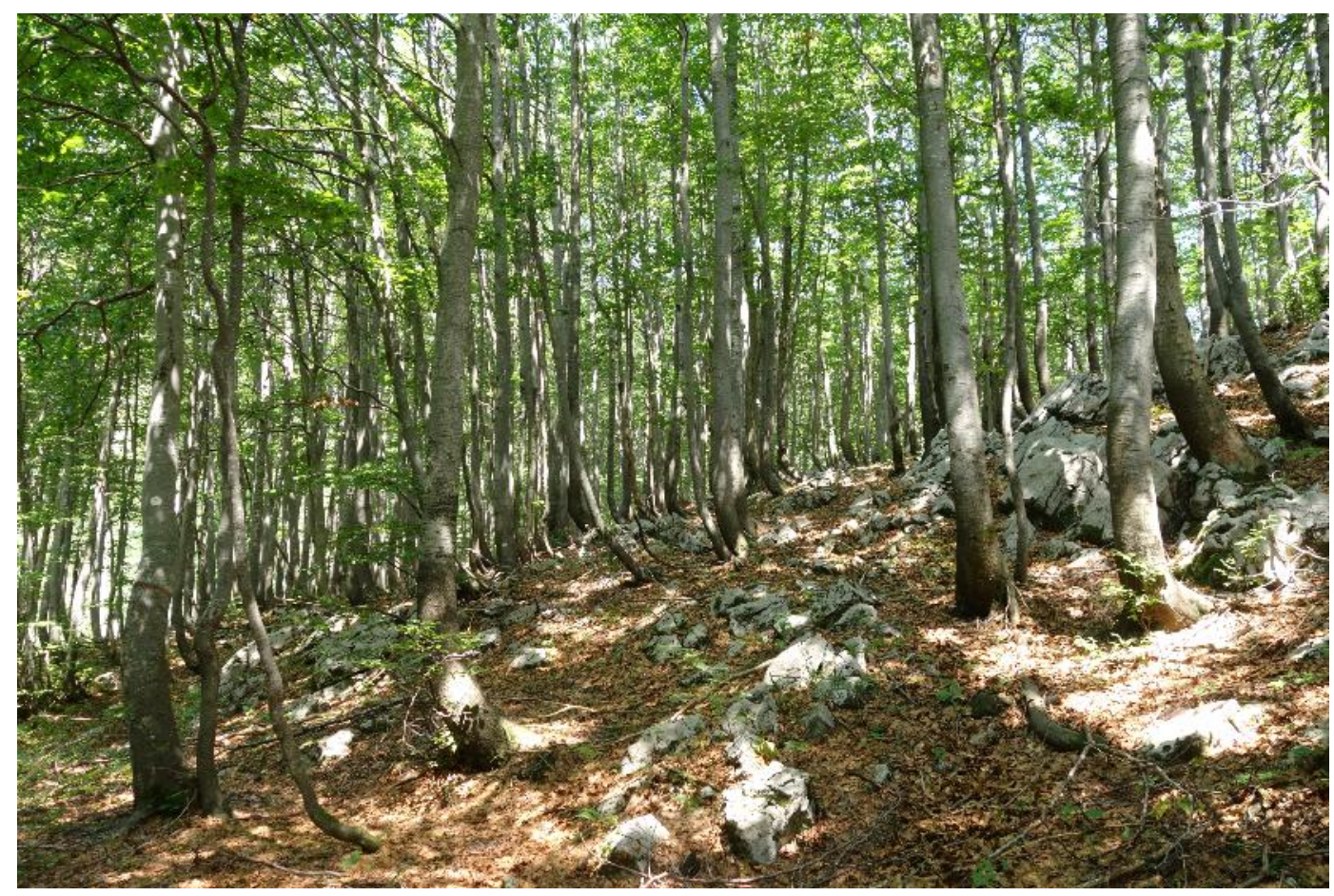

Slika 3. U pretplaninskoj bukovoj šumi s planinskim žabnjakom (Ranunculo platanifolii-Fagetum) bukova stabla postaju kvrgava i svijena pri bazi. (foto: D. Prlić)

Figure 3. Within the subalpine beech forest with large white buttercup (Ranunculo platanifoliiFagetum), beech trunks become increasingly gnarled and bent at the base. (photo: D. Prlić)

\section{Uspon od Rimskih vrata do posljednjih dijelova bukovih šuma}

Na ovom području nalazila se jedna od starih cesta koja je u prošlosti povezivala Čabar i Gerovo, prolazila dolinom Lazac te vodila dalje prema Rijeci i sjevernom Primorju (Feletar, 2015). Naime, prijevoj "Rimska vrata" predstavlja osobit sedlasti oblik reljefa koji dolazi neposredno prije završne dionice uspona (Slika 4). Glavni put (s markacijom) tako se dijeli na jedan odvojak koji se spušta u smjeru doline Lazac te drugi koji vodi prema vrhu Snježnika.

Za uže područje karakteristične su stjenovite južne padine i plitko tlo. Planinarska staza, naročito između vapnenačkih gromada, stanište je velikog broja vrsta, ponajviše termofilnih. Sljedeće vrste 
lako su prepoznatljive: pršljenasta kadulja (Salvia verticillata L.), obični mravinac (Origanum vulgare L.), balkanska majčina dušica (Thymus praecox Opiz ssp. polytrichus (A. Kern.ex Borbás) Jalas), planinska hudoljetnica (Erigeron glabratus Bluff et Fingerh.), sjajnolisna čestoslavica (Pseudolysimachion orchideum (Crantz) Wraber), sjajna broćika (Galium lucidum All.), gorska djetelina (Trifolium montanum L.) i srednji trputac (Plantago media L.). U skupini papratnjača među kamenjem su zabilježene bodljikava papratnjača (Polystichum aculeatum (L.) Roth), smeđa slezenica (Asplenium trichomanes L.), šumska paprat (Dryopteris filix-mas (L.) Schott) i nježna papratka (Cystopteris fragilis (L.) Bernh.). U florističkom sastavu bilježimo još grmove žestike (Rhamnus alpina L. ssp. fallax (Boiss.) Maire et Petitm.) te nekoliko "jastuka" planinske borovice (Juniperus communis L. ssp. nana Syme).

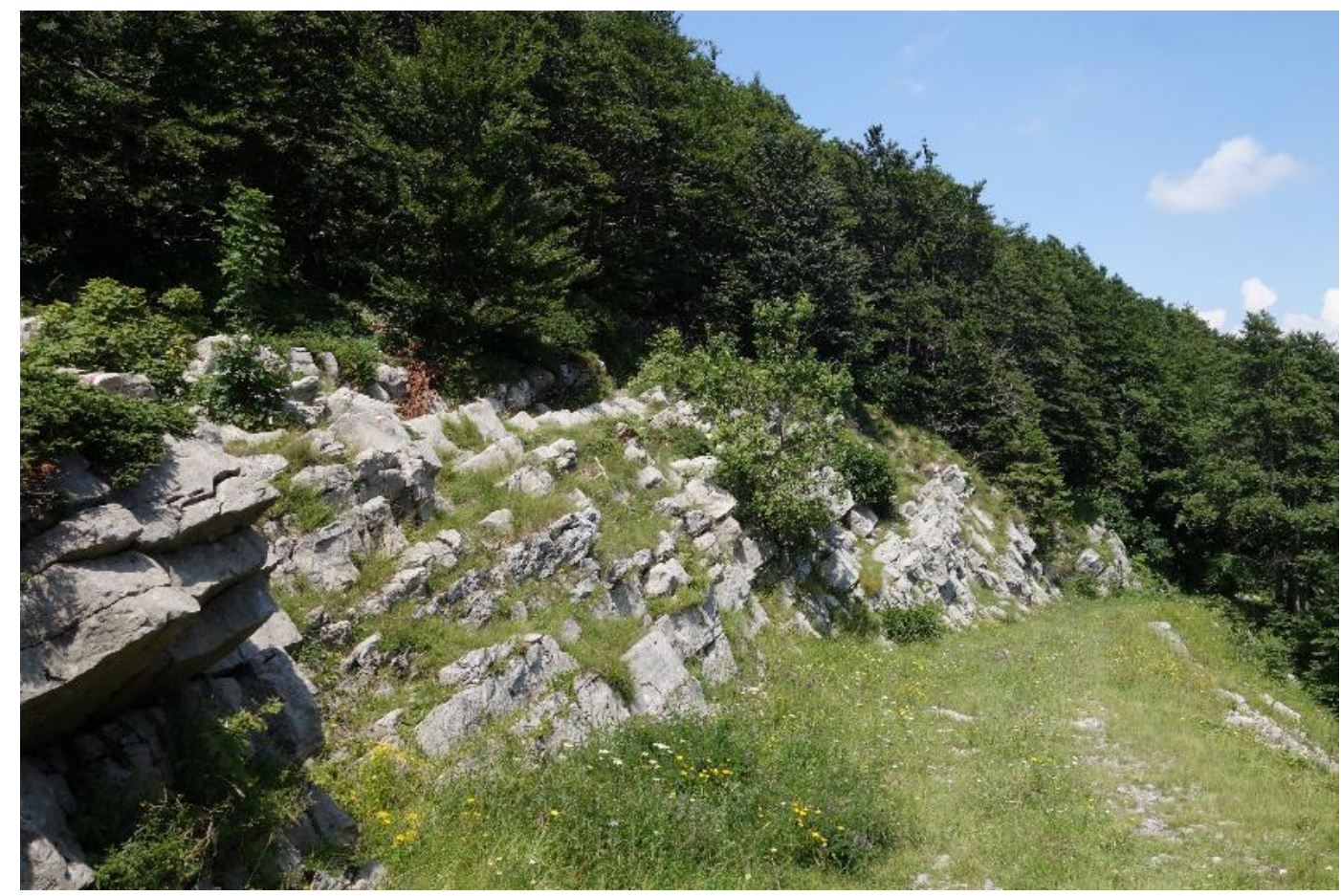

Slika 4. Prijevoj "Rimska vrata" nedaleko od vrha Snježnika. (foto: D. Prlić)

Figure 4. Mountain pass "Rimska vrata" is located close to the peak of Mt Snježnik. (photo: D. Prlić)

Nakon prelaska izohipse od 1350 m, pedološki profil šume sve jače prožima kamenje i krupne stijene. Nad njima se izdižu stabla bukve koja su zbog surovih zimskih uvjeta tanja i iskrivljenija nego u prethodnom pojasu. U vertikalnoj razdiobi vegetacije, na niži pojas pretplaninske bukove šume s platanastolisnim žabnjakom nadovezuje se pretplaninska bukova šuma s kopljastom paprati (Polysticho lonchitis-Fagetum /Horvat 1938/ Marinček in Poldini et Nardini 1993) (Slika 5). U pogledu stanišnih uvjeta ona nastanjuje kamenite vrhove te izložene i strme planinske grebene (Trinajstić, 2008; Vukelić, 2012). 
Dijagnostički značaj osim bukve (Fagus sylvatica) nosi i kopljasta paprat (Polystichum lonchitis (L.) Roth), uglavnom raširena uz baze kamenih gromada. Prizemno je prate mnoge vrste iz prijašnjeg pojasa, ali uz pojavu i nekih novih: lukovičasta režuha (Cardamine bulbifera (L.) Crantz), okruglolisna kamenika (Saxifraga rotundifolia L.), klasasta habulica (Actaea spicata L.), bijela šumarica (Anemone nemorosa L.), ljepljiva kadulja (Salvia glutinosa L.), crveni golesak (Silene dioica (L.) Clairv.), obična zlatnica (Solidago virgaurea L.), planinski luk (Allium victorialis L.) i dr. Poput bukove zajednice nižeg pojasa, ne ističe se njezino gospodarsko, već isključivo zaštitno značenje. U prošlosti se krčila za ogrjev, dobivanje pašnjačkih površina i izgradnju sezonskih nastambi (Vukelić, 2012).

Prije konačnog izlaska iz pretplaninske bukove šume, bukova stabla gube svoj tipični uspravni oblik i rastom poprimaju oblik klekovine - zaostaju kao svega par metara visoki grmovi.

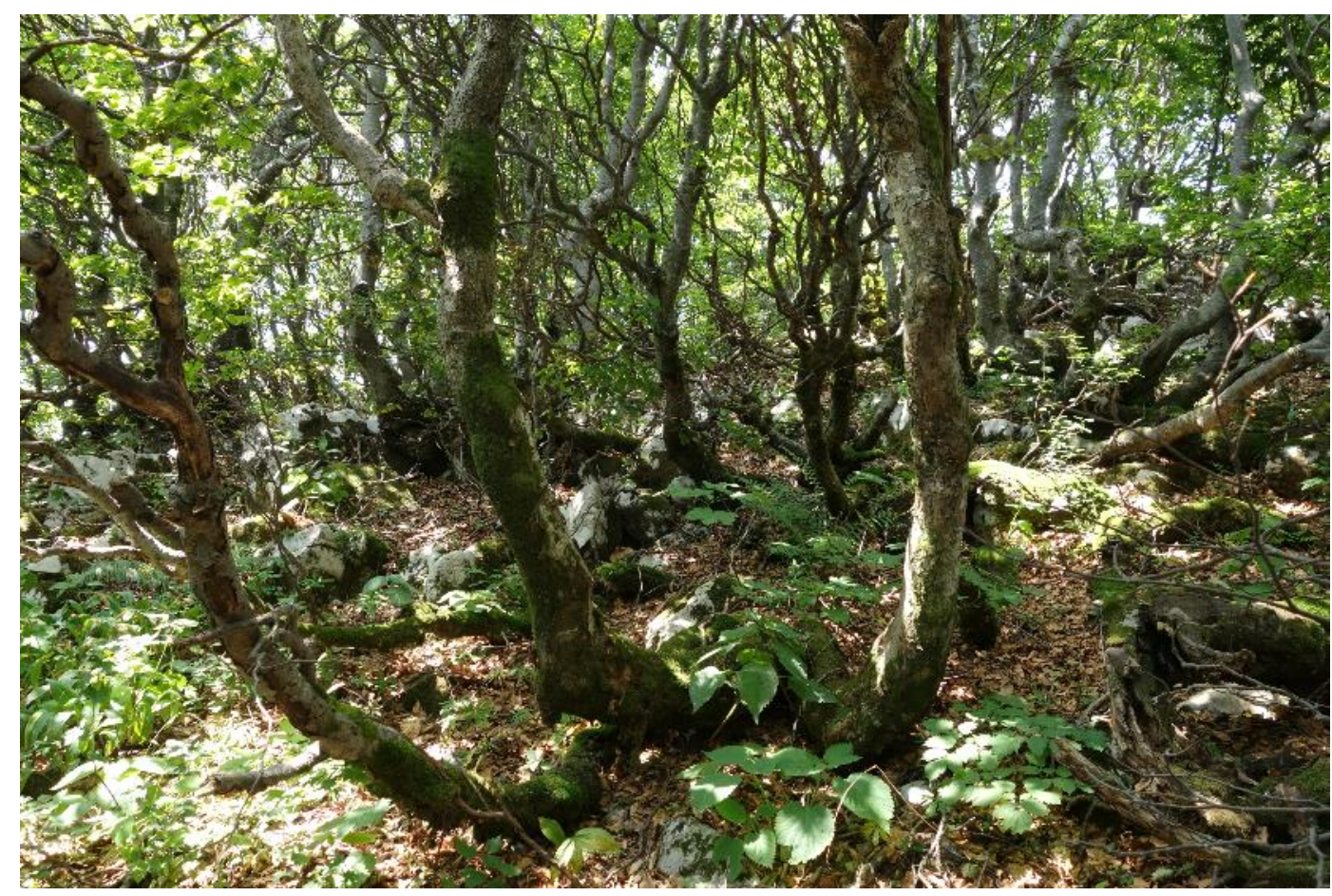

Slika 5. Neposredno pred izlaskom na planinske travnjake susreće se pretplaninska bukova šuma $\mathrm{s}$ kopljastom paprati (Polysticho lonchitis-Fagetum). (foto: D. Prlić)

Figure 5. A stand of subalpine beech forest with northern holly-fern (Polysticho lonchitis-Fagetum) occupies the area just below the mountain grasslands. (foto: D. Prlić)

\section{Raznolikost vegetacije na vršnim padinama Snježnika}

Mnoge biljne vrste prilagođene su oštrim klimatskim uvjetima ovih nadmorskih visina. Po južnom dijelu snježničkog masiva, već pri 1440 m nadmorske visine, rasijao se bor krivulj (Pinus mugo) prepoznatljiv po niskom i poleglom habitusu. Najljepše razvijena zajednica bora krivulja s alpskom pljuskavicom (Hyperico grisebachii-Pinetum mugi /Horvat 1938/ ex T. Wraber, Zupančič et Žagar 2004) proteže se od jugoistočnih prema sjevernim padinama Snježnika, od 1450 m pa gotovo do samog vrha (Slika 6). 
Premda fizionomski nalikuju na vegetaciju šikare, sastojine bora krivulja čine na hrvatskim planinama najviši šumski pojas na gornjoj granici prirodnoj razvoja šume (Bertović, 1975b). Ova klimazonalna zajednica zauzima stjenovite padine i vrhove, a uspijeva na vrlo malo planinske crnice sa sirovim humusom povrh karbonatne podloge (Vukelić, 2012). Također, uslijed temperaturne inverzije, sastojina bora krivulja može se pronaći i pri nižim nadmorskim visinama pa tako u Viljskoj ponikvi pored Risnjaka raste na 1184 m (Horvat, 1962; Vukelić 2012).

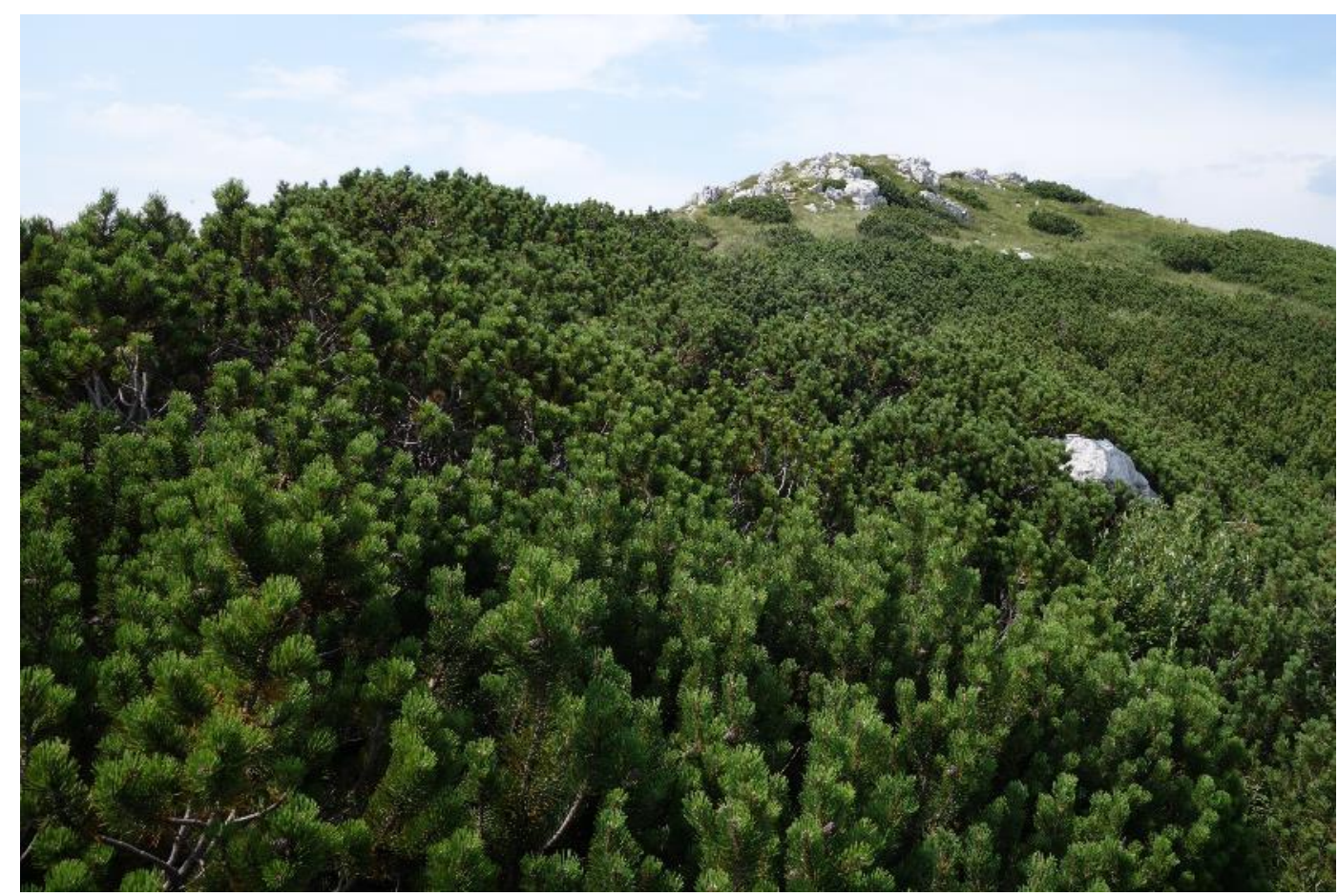

Slika 6. Izuzev najizloženijih dijelova, dinarske sastojine bora krivulja $\mathrm{s}$ alpskom pljuskavicom (Hyperico grisebachii-Pinetum mugi) pokrivaju mnoge grebene Snježnika. (foto: D. Prlić)

Figure 6. Dinaric stands of dwarf mountain pine (Hyperico grisebachii-Pinetum mugi) cover all except the most exposed areas of Mt Snježnik. (photo: D. Prlić)

Populacije bora krivulja rastu poprilično gusto, a oko njih ubacuju se svojstvene vrste kao što su: alpska pljuskavica (Hypericum richeri Vill. ssp. grisebachii (Boiss.) Nyman), Skopolijeva gušarka (Arabis scopoliana Boiss.), mukinjica (Sorbus chamaemespilus (L.) Crantz), Borbaševa kozokrvina (Lonicera borbasiana (Kuntze) Degen), planinski ribiz (Ribes alpinum L.), kupine kamenjarke (Rubus saxatilis L.), borovnice (Vaccinium myrtillus L.) i brusnice (Vaccinium vitis-idaea L.).

Prve površine nakon izlaska iz šumske vegetacije pripadaju planinskim rudinama vazdazelenog šaša i uskolisne šašike (Carici sempervirenti-Seslerietum juncifoliae Horvat in Horvat et al. 1974) te zauzimaju velike površine na putu prema vrhu planine (Slika 7). Karakteristične su upravo za masiv Snježnika, odnosno za sjeverozapadni dio hrvatskog dinarskog lanca (Trinajstić, 2008). U pogledu ekološke stratificiranosti, radi se o staništima relativno zaštićenih i kamenitih položaja na kojima, 
ovisno o reljefnim prilikama, zajednica gradi pojaseve različite širine. Od biljnih vrsta prevladavaju vazdazeleni šaš (Carex sempervirens Vill.) i uskolisna šašika (Sesleria tenuifolia Schrad. ssp. tenuifolia), a prate ih pustenasta zečina (Centaurea triumfetti All.), Žakenov ranjenik (Anthyllis montana L. ssp. jacquinii (A. Kern.) Hayek), planinska klečica (Juniperus communis L. ssp. nana Syme) i dr.

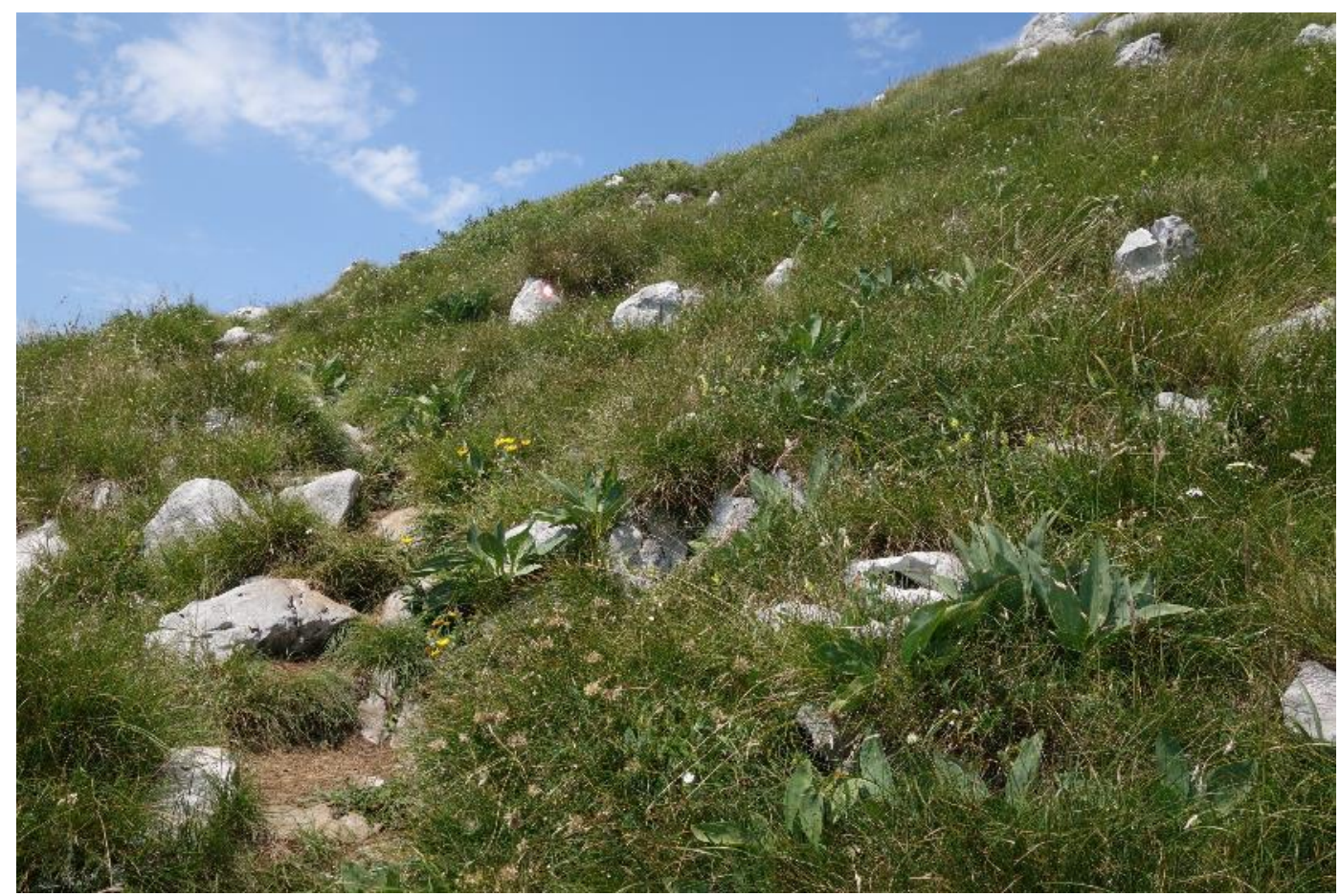

Slika 7. Planinske rudine vazdazelenog šaša i uskolisne šašike (Carici sempervirenti-Seslerietum juncifoliae) na otvorenim višim položajima. (foto: D. Prlić)

Figure 7. Alpine grasslands of evergreen sedge and moor grass (Carici sempervirenti-Seslerietum juncifoliae) spread over the exposed elevated areas. (photo: D. Prlić)

Na razmjerno zaštićenim položajima, kao što su sedla i periferni dijelovi ponikava, počinju se među kamenjem javljati rudine oštre vlasulje (Festucetum pungentis Horvat 1930). Nalaze se na strmim, toplim i od bure zaštićenim, razmjerno kamenitim položajima koji su zimi pokriveni snijegom (Horvat, 1962; Trinajstić, 2008). Kao karakteristične vrste ističu se: oštra vlasulja (Festuca bosniaca Kumm. et Sendtn.), divokozjački staračac (Senecio doronicum (L.) L.), livadna zvončika (Campanula glomerata L.), srpasti zvinčac (Bupleurum falcatum L.), dugodlakava smilica (Koeleria eriostachya Pančić), okruglasta zečica (Phyteuma orbiculare L.), balkanska majčina dušica (Thymus praecox Opiz ssp. polytrichus (A. Kern.ex Borbás) Jalas) i dr.

Rudine oštre vlasulje široko su raširene uz vrhove dinarskog gorja premda nisu svugdje jednako bujno razvijene. Iako je floristički i ekološki dobro izražena, zajednica je skromno zastupljena na Risnjaku, Snježniku i Bjelolasici, odnosno na dodiru alpske i dinarske vegetacije (Horvat, 1949). 
Manjih površina poznata je iz nižih dijelova na mjestima nekadašnje šumske vegetacije poput Ceclja i ponikve Veliko Snježno (Horvat, 1962), a zabilježena je još na Plješivici i Dinari (Trinajstić, 2008). Prestankom stočarenja ove se površine vraćaju šumama, prvenstveno sastojinama bukve (Fagus sylvatica), što je posljedica procesa sekundarne sukcesije.

Travnjaci dugodlake smilice i ljubičaste vlasulje (Koelerio-Festucetum amethystinae Horvat /1956/ 1962), kao dodatni oblik pretplaninskih travnjaka, naseljavaju mjesta ispod hrptova gdje razvučeni reljef ublažava strme padine. Oni dijele isti visinski položaj kao i rudine oštre vlasulje, međutim njihova ih ekologija veže za staništa na dubljem, ispranom i umjereno kiselom tlu (Trinajstić, 2008). Ekološki značaj zajednice leži i u povezivanju bazofilnih i acidofilnih biljnih elemenata (Horvat, 1962). Lijepo je razvijena po cijelom snježničkom kompleksu (Snježnik, Međuvrhi, Guslica) te u obližnoj ponikvi Veliko Snježno. Zajednica nosi naziv prema dijagnostičkim vrstama ljubičastocrvenoj vlasulji (Festuca amethystina L.) i dugodlakavoj smilici (Koeleria eriostachya Pančić).

Među travnjačkim zajednicama konačno ostaje za proučiti planinsku rudinu kitajbelovog šaša i alpske sunčanice (Helianthemo alpestri-Caricetum kitaibelianae Horvat 1930, nom. invers.) koja, u usporedbi s ranije navedenima, zauzima površine izložene najjačim naletima vjetra i hladnoće. Lokalizirana je oko samog vrha Snježnika pri čemu je vezana za južne ekspozicije i zaklone među kamenjem (Slika 8). U florističkom sastavu javlja se niz vrsta: Kitajbelov šaš (Carex kitaibeliana Bech.), planinska sunčanica (Helianthemum oelandicum (L.) DC. ssp. alpestre (Jacq.) Breistr.), uskolisna šašika (Sesleria tenuifolia Schrad. ssp. tenuifolia), glavičasti ušljivac (Pedicularis rostratocapitata Crantz), Kluzijev srčanik (Gentiana clusii E. P. Perrier et Songeon), vlasnata runjika (Hieracium villosum Jacq.), bijeli stolisnik (Achillea clavennae L.), Skopolijeva gušarka (Arabis scopoliana Boiss.), okruglasta zečica (Phyteuma orbiculare L.), križani žabnjak (Ranunculus hybridus Biria) i dr. Planinske rudine Kitajbelovog šaša i alpske sunčanice predstavljaju jednu od najznačajnijih asocijacija dinarskih planina (Horvat, 1962). 


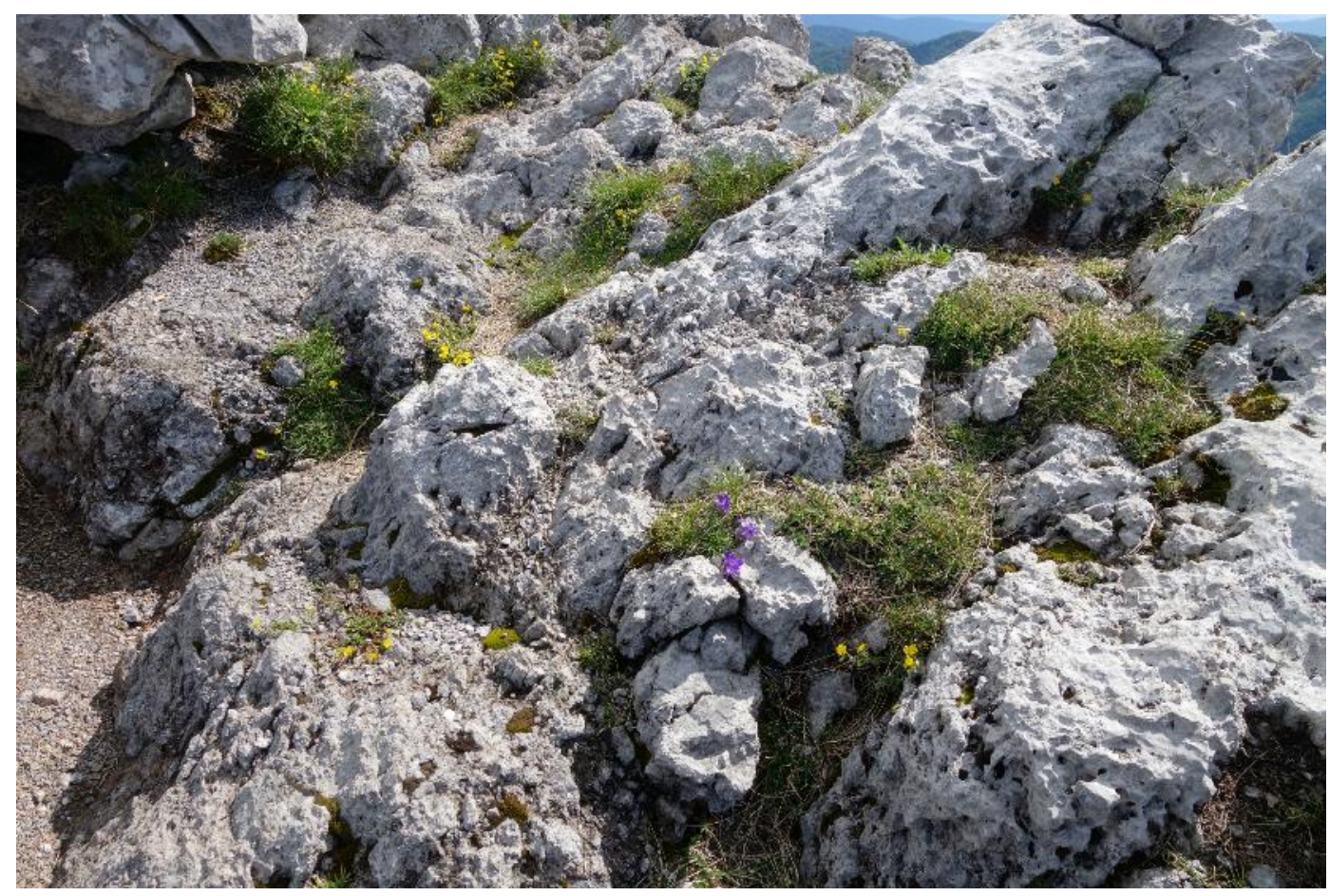

Slika 8. Segment planinske rudine Kitajbelovog šaša i alpske sunčanice (Helianthemo alpestriCaricetum kitaibelianae) na vrhu Snježnika. (foto: D. Prlić)

Figure 8. A section of the alpine grassland of Kitaibel's sedge and alpine rockrose (Helianthemo alpestri-Caricetum kitaibelianae) on the peak of Mt Snježnik. (photo: D. Prlić)

S vršnog dijela Snježnika $(1505 \mathrm{~m})$ lako se prate granice šumske vegetacije, raspored planinskih travnjaka kao i zajednice visokih zeleni u obližnjim ponikvama. Štoviše, pogled se otvara na susjednu Guslicu i Međuvrhe kroz koje planinarska staza prolazi prostranim travnjačkim površinama. U smjeru jugoistoka otvaraju se oštre i kamenite padine risnjačkog masiva. Mjestimično su potpuno gole ili tek s vegetacijom u pukotinama stijena, posebice na vršnim grebenima. Prema sjeveru ističu se doline Lazac i Šegine, a za povoljnog vremena pogled seže i do slovenskog Triglava.

\section{Osobite zanimljivosti biljnog svijeta}

Uz karakteristične indikatorske vrste koje su snažno vezane za pojedine biljne zajednice, dio florističkog sastava nerijetko predstavljaju i biljke od posebnog značaja koji može biti posljedica malih i prostorno ograničenih populacija, gubitka staništa ili statusa endemičnosti (usp. Anonymous, 2016; Nikolić i Topić 2005). Tako na početnom području oko Malog Platka nalazi svoje stanište lukovičavi ljiljan (Lilium bulbiferum L.) kao vrsta brdskih i gorskih livada. Zbog nekontroliranog sabiranja i oštećivanja dodijeljena mu je kategorija osjetljive (VU) biljne vrste (Regula-Bevilacqua, 2005a). Gotovo po svim padinama raste i ilirska prženica (Knautia illyrica Beck) kojoj je u hrvatskoj flori dodijeljen status endemske vrste (usp. Bogdanović, 2015). Dodatno, uslijed nedostatka podataka prema kojima bi se mogla izvršiti preciznija procjena ugroženosti, prema Crvenoj listi vaskularne flore 
kategorizirana je kao nedovoljno poznata vrsta (DD) (Nikolić, 2021), a ujedno predstavlja i strogo zaštićenu biljnu vrstu sukladno zakonskoj regulativi (Anonymous, 2016).

Oko velikog kamenja na obroncima Snježnika, podno neravnih i kvrgavih bukovih stabala, zabilježene su jedinke gotovo ugrožene (NT) šumske ciklame (Cyclamen purpurascens Mill.). Bijela nervatura listova i karakterističan cvijet čine šumsku ciklamu lako prepoznatljivom vrstom. Populacije pjegavog kaćuna (Dactylorhiza maculata (L.) Soó), kao i sve druge vrste orhideja (porodica Orchidaceae), strogo su zaštićene od bilo kakvog ubiranja ili oštećivanja. Zbog hladnije klime i odmaka vegetacijske sezone, sredinom srpnja pjegavi kaćun još uvijek cvate oko Snježnika, dok su u nižim područjima njegove populacije već ocvale. Za sloj grmlja značajna je prisutnost običnog likovca (Daphne mezereum L.), gotovo ugrožene vrste (NT) koja se pojavljuje na više mjesta tijekom uspona.

Obilaskom područja Rimskih vrata susrećemo nove pripadnike roda ljiljana (Lilium). Kranjski ljiljan (Lilium carniolicum Bernh. ex Koch) i ljiljan zlatan (Lilium martagon L.) obje nose status osjetljivih vrsta (VU) (Regula-Bevilacqua, 2005b, 2005c). Vezane su za visine od brdskog do planinskog pojasa, s time da kranjski ljiljan preferira stanišne prilike travnjaka, dok je ljiljan zlatan ekološki vezan za bukove i bukovo-jelove šume, a moguće ga je opaziti i uz šumske rubove. Strogo zaštićena orhideja šumska kokoška (Neottia nidus-avis (L.) Rich.), smeđe obojena i bez prisustva klorofila, raširena je na mnogim mjestima po šumi, pojedinačno ili u skupini od nekoliko jedinki.

Travnjaci padina Snježnika također obiluju vrijednim biljnih vrstama, no među šarenilom planinske flore nije ih uvijek lako opaziti. Žuta sirištara (Gentiana lutea L. ssp. symphyandra (Murb.) Hayek) predstavlja ugroženu vrstu (EN) čija brojnost u posljednje vrijeme pokazuje značajni pad. Posljedica je to prekomjernog sakupljanja podzemnih dijelova koji se primjenjuju u narodnoj medicini (Šegulja, 2005). Dio planinske flore su i bijeli stolisnik (Achillea clavennae L.), europska planinčica (Trollius europaeus L.) i planinska sasa (Pulsatilla alpina (L.) Delarbre), sve tri pripadaju gotovo ugroženim vrstama (NT). Štoviše, ni planinski travnjaci nisu izuzetak u pogledu orhidejske flore pa su zabilježene dvije strogo zaštićene vrste: bazgin kaćun (Dactylorhiza sambucina (L.) Soó) i mrežasti vranjak (Gymnadenia conopsea (L.) R. Br.). Obje su ekološki vezane za vapnenačke podloge (Kranjčev, 2005).

Oko samog vrha Snježnika gdje su klimatski uvjeti najsuroviji, nerijetko izvan dohvata ruku poput povišenih dijelova stijena, raste planinski runolist (Leontopodium alpinum Cass.) (Slika 9). Nekoliko jedinki runolista zabilježeno je i prilikom spusta među kamenjem na planinarskoj stazi. Naime, ova strogo zaštićena biljna vrsta i ikona planinara nije osobito zastupljena među vapnenačkim stijenama Snježnika. 


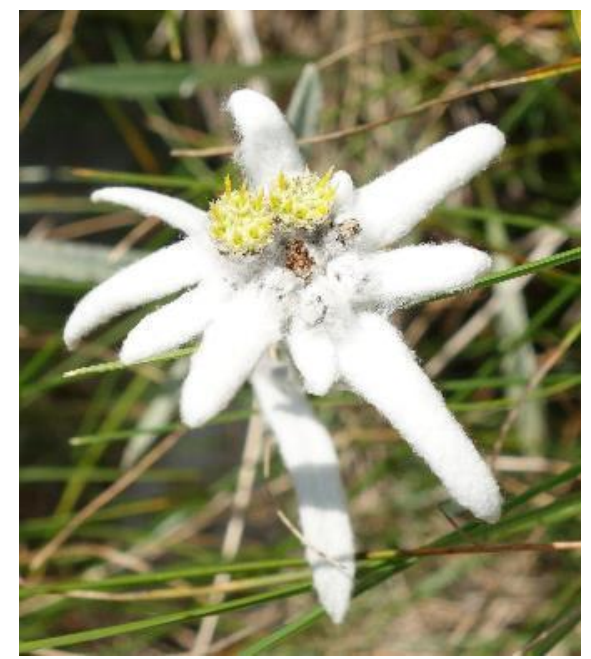

Slika 9. Planinski runolist (Leontopodium alpinum) u cvatu. (foto: D. Prlić)

Figure 9. The edelweiss (Leontopodium alpinum) in flower. (photo: D. Prlić)

\section{Zaključak}

Tijekom provedbe "Terenske nastave 3 - botanika" na području od Malog Platka prema vrhu planine Snježnik, kao dio studijskog programa Odjela za biologiju Sveučilišta Josipa Jurja Strossmayera u Osijeku, studenti 3. godine preddiplomskog studija biologije steći će kompetencije u prepoznavanju gradijenta klimazonalne vegetacije, pripadajućih biljnih vrsta te kombinacija biotičkih i abiotičkih čimbenika koji omogućavaju njihovu zastupljenost u prostoru. Premda terenska nastava na širem području Snježnika predstavlja tek jedan segment u višednevnom nastavnom angažmanu, ona istovremeno čini i nezaobilni dio mozaika cjelokupnog gradijenta vegetacije od nizinskog prema planinskom visinskom pojasu Hrvatske.

Terenska nastava koncipirana je prvenstveno kroz samostalni praktični rad studenata. Pri tome je posebna pažnja dodijeljena bilježenju reljefnih parametara i pratećih klimatskih prilika koje čine okosnicu vegetacijskog gradijenta. Izradom fitocenoloških snimaka studenti neposredno vježbaju determinaciju biljnih vrsta te stječu vještinu procjene ekoloških parametara vegetacije nužnih za definiranje biljnih zajednica. Dodatno, nakon obrade terenskih postaja, konzultacijom literature te analizom prikupljenih podataka, proširuju svoje spoznaje o ekologiji i arealu vegetacije Hrvatske. Cilj ovog koraka je potaknuti studente na pronalazak i prepoznavanje relevantnih podataka koji će im poslužiti u interpretaciji vegetacijskih fenomena.

U sklopu raznolike vegetacije i stanišnih uvjeta, ugrožene, strogo zaštićene pa čak i endemske biljne svojte nisu rijetkost. Nužno je ukazati na njihovo postojanje te ih pravilno prepoznati kako bi se izbjeglo ubiranje ili drugi vid nepotrebnog oštećivanja njihovih populacija. Konzervacijski statusi u pravilu proizlaze iz malog broja jedinki vrste ili degradacije njezinog staništa, stoga i ovaj aspekt 
terenske nastave doprinosi spoznajama o ekološkim vezama između živog svijeta i okoliša kojega nastanjuju.

Terenska opažanja i završna izvješća koja studenti izrade, uključujući povratne informacije od strane nastavnika, ostaju studentima kao potvrda o uspješno odrađenoj terenskoj nastavi te kao polazište za buduće botaničke angažmane.

\section{Literatura}

Anonymous (2001). Prostorni plan Nacionalnog parka Risnjak. Ministarstvo zaštite okoliša i prostornog uređenja. Županijski zavod za razvoj, prostorno uređenje i zaštitu okoliša u Rijeci, Rijeka.

Anonymous (2007). Nacionalni park Risnjak - Plan upravljanja. Ministarstvo kulture Republike Hrvatske. Javna ustanova Nacionalni park Risnjak, Crni Lug.

Anonymous (2016). Pravilnik o izmjenama i dopunama Pravilnika o strogo zaštićenim vrstama. Narodne novine 73/2016.

Bertović, S. (1975a). Prilog poznavanju odnosa klime i vegetacije u Hrvatskoj. Acta Biologica VII/2. Prirodoslovna istraživanja, knjiga 41. Zagreb: Jugoslavenska akademija znanosti i umjetnosti.

Bertović, S. (1975b): Ekološko-vegetacijske značajke okoliša Zavižana u sjevernom Velebitu. Glasnik za šumske pokuse, 18, 5-75.

Bogdanović, S. (2015). Knautia velebitica Szabó. U: Nikolić, T., Milović, M., Bogdanović, S., Jasprica, N. (ur.). Endemi u hrvatskoj flori. Zagreb: Alfa d. d.

Božičević, S. (ur.) (1993). Nacionalni park Risnjak - Hrvatska. Zagreb: Javno poduzeće NP Risnjak i JIVTOUR.

Feletar, P. (2015). Hrvatske povijesne ceste - Karolina, Jozefina i Lujzijana. Samobor: Izdavačka kuća Meridijani.

Griebl, N. (2018). Die Kosmos Alpenflora. Stuttgart: Franckh-Kosmos Verlags-GmbH \& Co.

Horvat, I. (1930). Vegetacijske studije o hrvatskim planinama I. Zadruge na planinskim goletima. Zagreb: Rad JAZU, 238, 1-96, Zagreb.

Horvat, I. (1931). Vegetacijske studije o hrvatskim planinama II. Zadruge na planinskim stijenama i točilima. Zagreb: Rad JAZU, 241, 147-206.

Horvat, I. (1949). Nauka o biljnim zajednicama. Zagreb: Nakladni zavod Hrvatske. 
Horvat, I. (1950). Istraživanje i kartiranje vegetacije planinskog skupa Risnjaka i Snježnika. Šumarski list, 3-4, 97-118.

Horvat, I. (1952/53). Vegetacija ponikava - prilog biljnoj geografiji krša. Geografski glasnik, 14/15, $1-25$.

Horvat, I. (1955). Osam godina istraživanja i kartiranja vegetacije Gorskog kotara i Hrvatskog primorja. Šumarski list, 11-12, 412-422.

Horvat, I. (1962). Vegetacija planina Zapadne Hrvatske. Acta Biologica II. Prirodoslovna istraživanja, knjiga 30. Zagreb: Jugoslavenska akademija znanosti i umjetnosti.

Jávorka, S., Csapody, V. (1991). Iconographia florae partis austro-orientalis Europae centralis. Budapest: Adadémiai Kiadó.

Kovačić, S., Nikolić, T., Ruščić, M., Milović, M., Stamenković, V., Mihelj, D., Jasprica, N., Bogdanović, S., Topić, J. (2008). Flora jadranske obale i otoka - 250 najčešćih vrsta. Zagreb: Školska knjiga.

Kranjčev, R. (2005). Hrvatske orhideje - prilozi za hrvatsku floru. Zagreb: Agencija za komercijalnu djelatnost d.o.o.

Nikolić, T. (2019). Flora Croatica 4 - Vaskularna flora Republike Hrvatske. Zagreb: Alfa d.d.

Nikolić, T. (2021). Flora Croatica Database. Prirodoslovno-matematički fakultet, Sveučilište u Zagrebu. Url: hirc.botanic.hr/fcd/CrvenaKnjiga/. Posjećeno 17.2.2021.

Nikolić, T., Topić J. (ur.) (2005). Crvena knjiga vaskularne flore Republike Hrvatske. Zagreb: Ministarstvo kulture. Državni zavod za zaštitu prirode.

Poljak, Ž. (2008). 50 najljepših planinarskih izleta u Hrvatskoj. Zagreb: Školska knjiga, Zagreb.

Regula-Bevilacqua, Lj. (2005a). Lilium bulbiferum L. U: Nikolić, T., Topić, J. (ur.). Crvena knjiga vaskularne flore Hrvatske. Zagreb: Ministarstvo kulture, Državni zavod za zaštitu prirode.

Regula-Bevilacqua, Lj. (2005b). Lilium carniolicum Bernh. ex Koch. U: Nikolić, T., Topić, J. (ur.). Crvena knjiga vaskularne flore Hrvatske. Zagreb: Ministarstvo kulture, Državni zavod za zaštitu prirode.

Regula-Bevilacqua, Lj. (2005c). Lilium martagon L. U: Nikolić, T., Topić, J. (ur.): Crvena knjiga vaskularne flore Hrvatske. Zagreb: Ministarstvo kulture, Državni zavod za zaštitu prirode. 
D. Prlić / Prikaz visinskog gradijenta vegetacije od Malog Platka prema vrhu Snježnika (Hrvatska) / Glasilo Future (2021) 4 (1) 33-52

Šegulja, N. (2005): Gentiana lutea L. ssp. symphyandra (Murb.) Hayek. U: Nikolić, T., Topić, J. (ur.): Crvena knjiga vaskularne flore Hrvatske. Zagreb: Ministarstvo kulture, Državni zavod za zaštitu prirode.

Šegulja, N., Lovašen-Eberhard, Ž., Hršak, V., Lukač, G. (1994). Prikaz stanja istraženosti flore u NP "Risnjak". Zbornik radova 40 godina NP "Risnjak", Crni Lug.

Topić, J., Ilijanić, Lj., Tvrtković, N., Nikolić, T. (2006). Staništa - priručnik za inventarizaciju, kartiranje i praćenje stanja. Zagreb: Državni zavod za zaštitu prirode.

Trnajstić, I. (2008). Biljne zajednice Republike Hrvatske. Zagreb: Akademija šumarskih znanosti.

Vitasović Kosić, I., Šipek, M., Šajna, N. (2020). Prikaz studentske terenske nastave na širem području mjesta Plomin (Plominska gora, Hrvatska). Glasilo Future, 3(3), 34-50.

Vukelić, J. (2012). Šumska vegetacija Hrvatske. Zagreb: Šumarski fakultet Sveučilišta u Zagrebu, Državni zavod za zaštitu prirode.

Vukelić, J., Rauš, Đ. (1998). Šumarska fitocenologija i šumske zajednice u Hrvatskoj. Zagreb: Šumarski fakultet Sveučilišta u Zagrebu.

Vukelić, J., Mikac, S., Baričević, D., Bakšić, D., Rosavec, R. (2008). Šumska staništa i šumske zajednice u Hrvatskoj. Zagreb: Državni zavod za zaštitu prirode.

Primljeno: 01. ožujka 2021. godine

Prihvaćeno: 17 . svibnja 2021. godine
Received: March 01, 2021

Accepted: May 17, 2021 